\title{
MANAGEMENT OF SEPTORIA LEAF SPOT DISEASE IN TOMATO AT BHAKTAPUR
}

\author{
Khyaju, S. ${ }^{1}$, K.C., G ${ }^{2}$, Timila, R. ${ }^{3}$, Shrestha, S. ${ }^{4}$ \\ Institute of Agriculture and Animal Sciences, Post Graduate Campus, Kirtipur, Kathmandu
}

\begin{abstract}
A farmers' field survey was conducted during 2014 in Bhaktapur district to study socioeconomic status, agricultural practices and occurrence of Septoria Leaf Spot (Septoria lycopersici Mill.) of tomato and its management practices using random sampling of 25 respondents. Field experiment on management of Septoria Leaf Spot was conducted in a completely randomized design (CRD) with six treatments and four replications. The six treatments were i) Astha Killer 15 (Azadirachta indica) 1500ppm, ii) Cow Urine (@ $5 \%$ concentration of cow urine; solar activation for 48 hours), iii) Neem $(2 \mathrm{ml} / \mathrm{l}$ water $)+$ cow urine $(5 \%)$ (1:1 ratio; final solution of 2ml/1 water), iv) Chlorothalonil @ 2.5gm/lt water, v) Mancozeb (@2.5gm/lt water), and vi) control (water). Majority of farmers (70\%) raised seedlings by themselves. Septoria Leaf Spot disease was the third important disease after Late Blight and viral disease. Septoria Leaf Spot disease was found in farms of $84 \%$ respondents. Septoria Leaf Spot symptom was found in leaf and both in leaf and stem in $47.62 \%$ and $52.38 \%$ respondents respectively. The disease incidence in field of $85.71 \%$ respondents was since 1-2 years. Higher relative humidity, higher precipitation and higher temperature were congenial for disease development. $80 \%$ of the respondents used synthetic fungicides for controlling the disease, where Mancozeb and Chlorothalonil were used by $44 \%$ and $20 \%$ respectively. Mancozeb was found most effective in controlling disease, followed by Chlorothalonil. Among the botanical treatments, Neem $(2 \mathrm{ml} / \mathrm{l}$ water $)+$ Cow urine $(5 \%)$ was found effective in disease control than other two botanical treatments.
\end{abstract}

Key words: Septoria Leaf Spot, Neem, Mancozeb, Cow urine, botanical treatment

\section{INTRODUCTION}

Tomato (Lycopersicon esculentum Mill.) is the most important vegetable grown in the world (Saravanan et al., 2003). It is one of the major commercial vegetable crops and widely grown both in the plains and hills of Nepal. In Nepal, the area under tomato is about 19,728 ha with a production of 2,98,594 MT and productivity of $15.1 \mathrm{MT} / \mathrm{ha}$ (Year Book, 2013). Conventionally, tomato is grown popularly as winter crop in plains and summer crop in the hills. In the plains, tomato can be produced successfully as winter to spring season crop and as offseason in two growing seasons, spring (slightly later) and rainy to autumn (slightly earlier). It can be produced year round in protected conditions. Ripened fruits are good source of Ascorbic acid, organic acids and minerals. The gradual and ever increasing year round demand of tomato for fresh consumption and processing is due to increasing urbanization, hotels, tourism, nutritional awareness of the people, etc. "Srijana" is an indigenous popular hybrid variety of tomato in Nepal. It has average fruit weight of 50-60gm.

Among various diseases Septoria leaf spot caused by Septoria lycopersici Speg., (Mycosphaerellaceae) is one of the economically important foliar diseases. Under humid regions, particularly during the periods of rainfall, it incurs loss both at pre- and post-harvest stages in tomato. The causal fungus grows on potato dextrose agar (PDA) produced dull white mycelium with flexuous and filiform hyaline conidia, with 1-9 septations. Under computerized predictive system, TOMCAST software is being used for forcasting of the disease (Agrios, 2005).

Septoria leaf spot is an important disease on cultivated tomato around the world (Stevenson, 1991). It was first reported in Argentina in 1882 and later in the United States in 1896 (Sutton \& Waterston, 1966). The importance of this disease depends on weather conditions, being

${ }^{1}$ Student (M. Sc. Ag., Plant Pathology), 2Prof. (Plant Pathology), ${ }^{3}$ Prof. (Plant Pathology), ${ }^{4}$ Prof. (Plant Pathology) 
favored by high moisture and temperatures. In these conditions it can cause severe defoliation and consequently significant yield losses due to sun-scald of the fruits (Stevenson, 1991; Ferrandino and Elmer, 1992). Lincoln and Cummins (1949) in the USA, reported 80\% defoliation and Sohi andSokhi (1974) in India reported almost 100\% defoliation, due to this disease. Erinleet al. (1986) reported that in Northern Nigeria $S$. lycopersici was the only serious problem, during three consecutive years, in unprotected tomato cultivars.

A two-year (2007-2008) survey of nine tomato farms in three local government areas of Edo State (Esan central, Esan West and Esan North East) which are the main tomato growing areas of Edo State, revealed that Septoria leaf spot disease of tomato was of major concern, affecting $14.9-24.3 \%$ of the crops in the farms. Mature leaves were found to be more susceptible to the disease than younger ones. Resistant cultivars maintained their leaves even under severe infection and hence protected the fruits from sunscald while susceptible cultivars lost their leaves under moderate infestation by the Septoria. (Mensah et al., 2008)

\section{Septoria leaf spot disease in Nepal}

Septoria leaf spot has been observed in Nepal since many years. The disease is widespread in tomato growing areas. In severe conditions, it causes severe premature defoliations as well as drying of the entire plant and may cause severe yield loss. It has potentiality of being havoc in future if necessary management measures are not adopted. (Personal communication, Ramesh Baidya, Thimi, Bhaktapur)

\section{MATERIALS AND METHODS}

The study consisted of three parts: farmers' survey, laboratory study and a field experiment.

\subsection{Farmers' survey}

A survey was conducted to find out the incidence, severity and management of Septoria leaf spot in tomato in farmers' fields from six municipalities of Bhaktapur district. Twenty five tomato growers were taken under observation. Necessary households were used for pretest survey and necessary changes were made. Survey questionnaire (semi-structured) was prepared and necessary information were collected. Respondents were from Mahamanjushree Nagarkot Municipality, Madhyepur Municipality, Suryabinayak Municipality, Changunarayan Municipality, Anantalingeswor Municipality and Bhaktapur Municipality. The more number of selections of farmers from Mahamanjushree Nagarkot Municipality is due to more number of tomato growers present. Questionnaire was asked with the head of the family. In absence of household head, next senior of the household was taken as the respondent. Collected information was tabulated, analyzed and interpreted with the help of relevant literatures.

\subsection{Laboratory study}

For laboratory test of the Septoria leaf spot disease, affected plant parts were collected from each respondent. Clean scissor was used for taking samples and were put in clean plastic bag. Both affected stems and leaves were collected. The samples were taken and observed in laboratory of Plant Pathology Division, National Agriculture Research Council (NARC), Khumaltar and Department of Agriculture, Hariharbhawan, Lalitpur. 


\subsection{Field experiment}

\subsubsection{Experimental site}

The field experiment and design was conducted in a plastic house in Jhaukhel, Changunarayan municipality at the northern part of the Bhaktapur district (Figure 5). The site was $14 \mathrm{~km}$ away from Kathmandu district. The latitude and longitude of the site was $27^{\circ} 41^{\prime} \mathrm{N}$ and $85^{\circ} 25^{\prime}$ E respectively, with an elevation of $1319 \mathrm{~m}$ from sea level. The study was carried out in Completely Randomized Design (CRD) with six treatments and four replications.

Astha Killer 15 (Neem pesticide, Lila Agrotech, Rajibpur, North 24 Parganas, WB, India a.i. Azadirachtin 1500ppm) @ 2 $\mathrm{ml} \mathrm{1}^{-1}$ water, cow urine (urine of improved cow, solar activated for 48 hours in direct sunlight) @ 5\%, Neem + cow urine ( $1 \mathrm{ml}$ of Astha Killer 15 @ $2 \mathrm{ml} \mathrm{l}^{-1}$ water $+1 \mathrm{ml}$ of cow urine @ 5\% water; final solution of $2 \mathrm{ml} \mathrm{l}^{-1}$ water), Chlorothalonil @ 2gm $1^{-1}$ water, Mancozeb@2gm 1-1 water and control (water spray).

One liter of the treatment solution was applied in four plots. Fungicides were applied in afternoon. 2 liter sprayer was used to spray the fungicides. Foliar spray was implied to wet all aerial parts of plants. Interval of application of treatments was 7 days.

\subsubsection{Selection of plants for disease assessment}

In each plot numbering of the plants was done in Serpentine method. Four plants were selected randomly per plot for recording data.

$$
\begin{gathered}
\text { Percentage Incidence of the Disease }=\frac{\text { Number of Plants infected }}{\text { Total number of plants (infected and uninfected) }} \times 100 \% \\
\text { Disease Severity Percent }=\frac{\text { Sum of all disease rating }}{\text { Total number of plants observed } \times \text { Maxm. disease rating grade }} \times 100 \%
\end{gathered}
$$

\subsubsection{Disease Sample collection}

The Septorial disease plants parts were collected from the experiment field, i. e. Changunarayan Municipality. It was taken in plastic bags and brought to the laboratory for isolating the disease-causing fungi.

\subsubsection{Isolation and identification of pathogen}

Diseased portion of the tomato plants were segmented with the aid of scalpel and needle. Under laminar flow, the segments were placed on petri-dishes containing PDA. Inoculated petridishes were incubated at room temperature and observed daily. The fresh growth of the fungi was transferred to freshly prepared potato-dextrose agar medium for sub-culturing. Based on morphology, the fungi isolated was identified under microscope by studying their typical conidia growth and septated elongated pycniospores produced on the potato dextrose agar medium.

\subsubsection{Laboratory work}

Laboratory testings were conducted in laboratories of National Agricultural Research Council (Plant Pathology Division, NARC), Khumaltar and Department of Agriculture (DOA), Hariharbhawan, Lalitpur. Infected plant parts preservation was done in incubator at room temperature. Preparation of PDA medium, transfer of infected samples in petri-dishes, disease 
slide preparation was done in UV laminar flow under sterilized condition. Conidia, pycnidia and other parts of Septoria were studied under under microscope.

\subsubsection{Disease Scoring}

The disease intensity was scored after McKinney's scale (0-4) as applied by Horsfall and Heuberger (1942) with slight modification as follows:

$0=$ infection free

$1=$ trace to $20 \%$ of leaf areas affected,

$2=21-40 \%$ leaf areas affected,

$3=41-60 \%$ leaf areas affected, and

$4=$ more than $60 \%$ of the leaf areas affected.

\subsubsection{Statistical analysis}

Data entry was done in MS-EXCEL and SPSS. Data were analysed using SPSS. 'R' software (2014, Warm Puppy) was used for analysis of variance and mean comparisons. Graph and figures were generated using SPSS software and MS-EXCEL.

\subsection{Farmers' survey}

\section{RESULTS AND DISCUSSION}

\subsubsection{Farmers' profile}

While studying the educational status of the sampled households, $4 \%$ of the tomato growers were found illiterate. $40 \%$ were found literate. $28 \%, 4 \%$ and $24 \%$ households had completed SLC, Intermediate, Bachelor and Graduate and above level education respectively.

The data regarding household survey of the respondents, $20 \%$ had equals to or less than 5 members $(80 \%)$ and 5 respondents had 6-10 members.

All the respondents of the survey area were tomato growers. The land coverage of tomato farm range from 0.5 ropani to 27 ropani.

\subsection{Field survey}

Among selected farmers, seventy percent raised tomato seedlings themselves, twelve percent buy from market while sixteen percent do both.

Survey showed that hundred percent of the farmers observed their tomato farm with the presence of disease. They also observed for the performance of the fungicides used in their farms. This is a good indication of farmers' awareness. The survey showed thirty two percent, thirty two percent and thirty six percent farmers observed field monthly, weekly and daily respectively. This shows farmers are conscious on disease occurrence in their field.

\subsection{Diseases prevalent in Bhaktapur}

Among the tomato growers $60 \%$ farmers had the problem of late blight. Viral disease, Septoria leaf spot disease and bacterial wilt comprised of 20\%, $12 \%$ and $8 \%$ respectively (Table 9). The data indicated Septoria leaf spot as the third major disease. It could be more havoc in near future if proper care is not taken on time. 


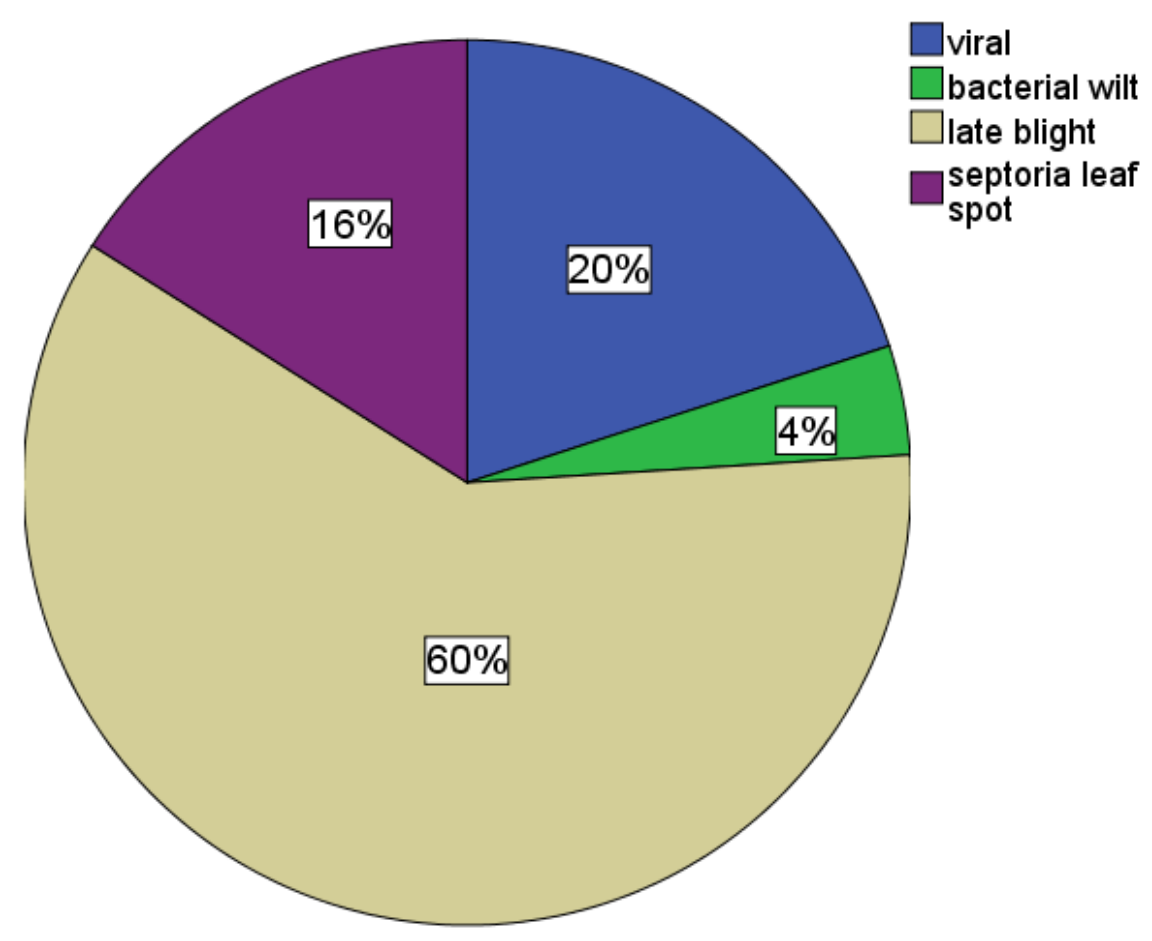

Figure 1 Diseases prevalent in Bhaktapur

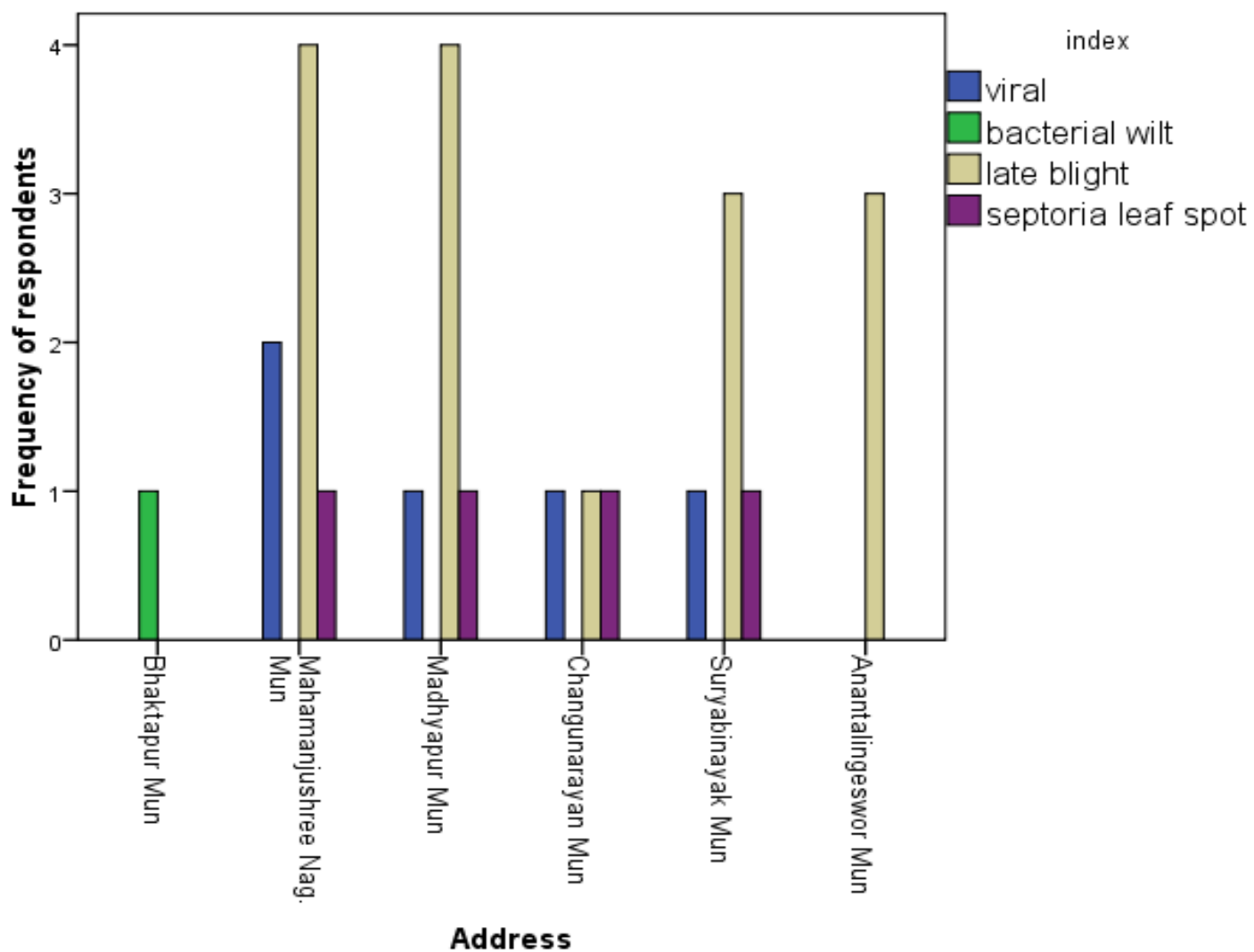

Figure 2: Diseases presence and farmers' response 


\subsection{Presence of Septoria leaf spot}

Septoria leaf spot was found in $84 \%$ farmers while remaining had no any disease (Table 11). The samples were collected in plastic sheet and tested in laboratory of Plant Pathology division, NARC. This could be because of conducive environmental conditions for spore release and dissemination during the cropping period. Environmental factors, such as, wind and leaf wetness period and intercultural operations could also enhance spore dissemination. Structure of the tunnel can also affect the disease spread.

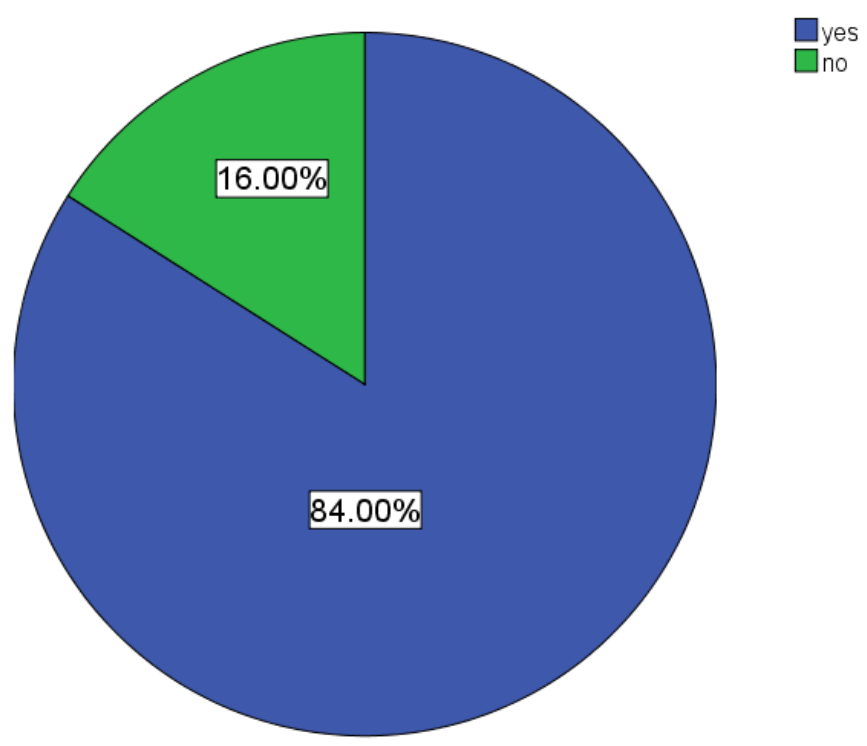

Figure 3: Presence of Septoria disease and farmers' response Table 1. Presence of Septoria leaf spot

\begin{tabular}{lll}
\hline Presence of Septoria & Frequency & Percent \\
\hline Yes & 21 & 84 \\
No & 4 & 16 \\
\hline Total & 25 & 100 \\
\hline
\end{tabular}

Table 2. Presence of Septoria based on location

\begin{tabular}{lcc}
\hline Address & Presence of Septoria & No \\
\hline Mahamanjushree Nagarkot Municipality & Yes & 1 \\
Suryabinayak Municipality & 6 & 0 \\
Anantalingeswor Municipality & 5 & 0 \\
Changunarayan Municipality & 3 & 0 \\
Madhyapur Municipality & 3 & 3 \\
Bhaktapur Municipality & 3 & 0 \\
\hline Total & 1 & 4 \\
\hline
\end{tabular}




\subsection{Plant parts affected}

The study showed that $40 \%$ respondents replied leaf of the plants had symptoms of Septoria leaf spot, $44 \%$ had both on leaf and stem and $16 \%$ had no any disease symptoms on the plants. No symptoms were observed on fruits.

Table 32. Plant parts affected by the disease

\begin{tabular}{lcc}
\hline Plant parts & Frequency & Percent \\
\hline Leaf & 10 & 40 \\
Leaf and stem & 11 & 44 \\
No symptoms & 4 & 16 \\
\hline Total & 25 & 100 \\
\hline
\end{tabular}

\subsection{Prevalence of the disease}

Seventy two percent farmers reported that Septoria Leaf Spot appeared since 1-2 years, while twelve mentioned since 3-5 years in their tomato field. Sixteen percent farmers did not notice the disease. (Table 14)

Table 3. History of disease prevalance

\begin{tabular}{lll}
\hline Year & Frequency & Percent \\
\hline $1-2$ & 18 & 72 \\
$3-5$ & 3 & 12 \\
No disease & 4 & 16 \\
\hline Total & 25 & 100 \\
\hline
\end{tabular}

\subsection{Incidence of disease}

Twenty four percent farmers had their farm with $41-50 \%$ disease incidence. Sixteen percent of the farmers' farm had $11-20 \%$ disease incidence. The weighted mean incidence of disease is $42.61 \%$ farm. The reason behind the disease spread might due to improper cultivation practices.

Table 4. Disease incidence $(n=25)$

\begin{tabular}{lll}
\hline Disease incidence & Frequency & Percent \\
\hline $0-10 \%$ & 1 & 4 \\
$11-20 \%$ & 4 & 16 \\
$21-30 \%$ & 2 & 8 \\
$31-40 \%$ & 2 & 8 \\
$41-50 \%$ & 6 & 24 \\
$51-60 \%$ & 2 & 8 \\
$61-70 \%$ & 1 & 4 \\
$71-80 \%$ & 1 & 4 \\
$81-90 \%$ & 2 & 8 \\
$91-100 \%$ & 4 & 16 \\
\hline Total & 25 & 100 \\
\hline
\end{tabular}

\subsection{Role of environmental factors on disease development}

Majority of farmers (60\%) considered high temperature was responsible for Septoria leaf spot disease development. Thirty six percent and four percent farmers considered for medium and low temperature respectively. Sixty percent of the farmers considered high humidity responsible for the disease development while $40 \%$ considered the medium humidity for disease 
development. Seventy two percent of the farmers considered high rainfall responsible for the disease development and only $28 \%$ farmers considered medium rainfall for disease development.

Farmer's knowledge on environmental factor affecting the Septoria Leaf Spot is shown in table below.

Table 5. Farmer's response on environmental factor affecting Septoria Leaf Spot disease infestation $(\mathrm{n}=25)$

\begin{tabular}{lll}
\hline Environmental factor & Frequency & Percent \\
\hline Temperature & & \\
\hline High & 15 & 60 \\
Medium & 9 & 36 \\
Low & 1 & 4 \\
\hline Humidity & & 60 \\
\hline High & 15 & 40 \\
Medium & 10 & 0 \\
Low & 0 & \\
\hline Rainfall & & 72 \\
High & 18 & 28 \\
Medium & 7 & 0 \\
Low & 0 & \\
\hline
\end{tabular}

\subsection{Disease severity}

Each forty percent of farmers farm had disease severity of $<10 \%$ and $10-25 \%$. Only $4 \%$

farmers' farm had $26-50 \%$ disease severity. The weighted mean of disease severity is $12.5 \%$. This indicates the disease has become a problem.

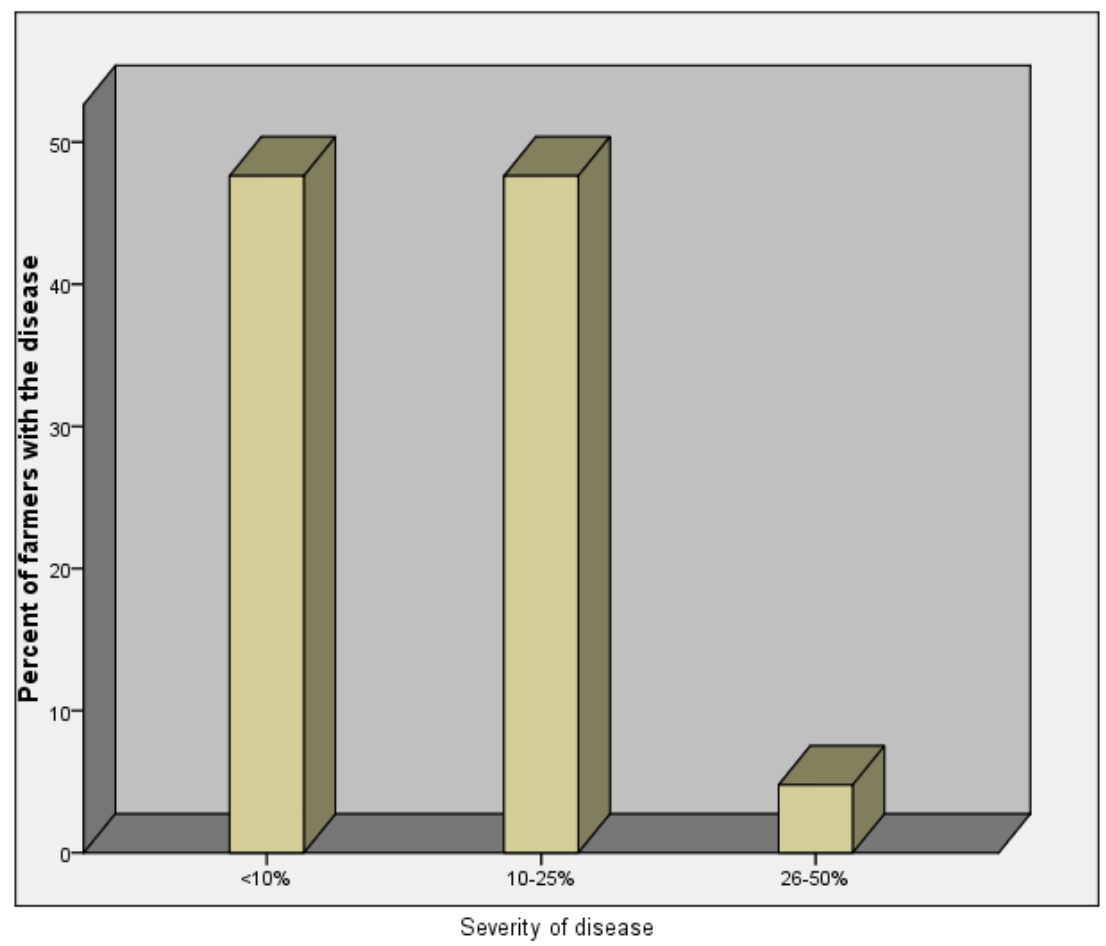

Figure 4 Disease severity of Septoria disease in farm of respondents 


\subsection{Septoria disease problem}

Septoria leaf spot is problem to around fifty two (52\%) of farmers. This indicates the disease spread in Bhaktapur has become havoc.

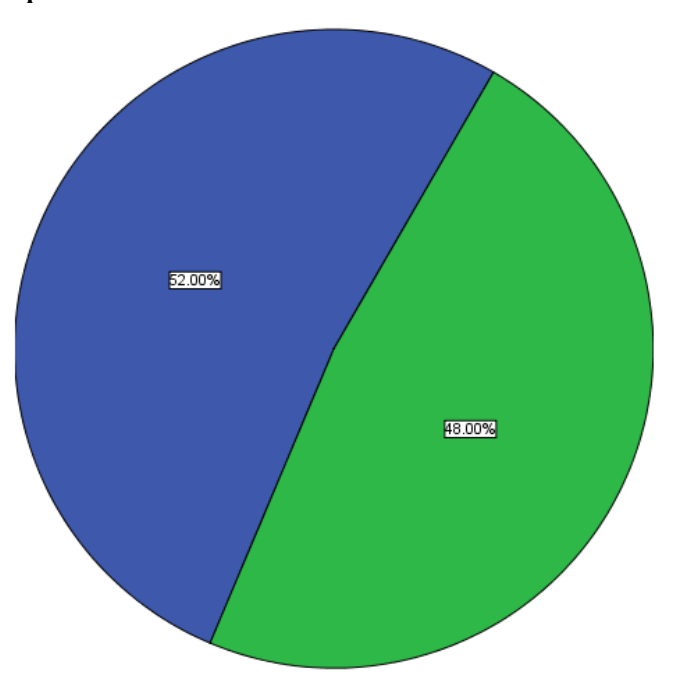

瞄皆

Figure 5. Septoria disease as problem in farms of respondents

\subsection{Use of fungicides to control the disease}

Based on survey, eighty percentages of the respondents used synthetic fungicides for controlling Septoria leaf spot. Among them Mancozeb, Chlorothalonil, Bavistin and no use of fungicides were forty four percentages, twenty percentages, sixteen percentages and twenty percentages respectively. The cause behind the use of Mancozeb could be the better efficacy of it in controlling fungal disease as board spectrum nature.

Use of fungicides to control the Septoria Leaf Spot in tomato in Bhaktapur 


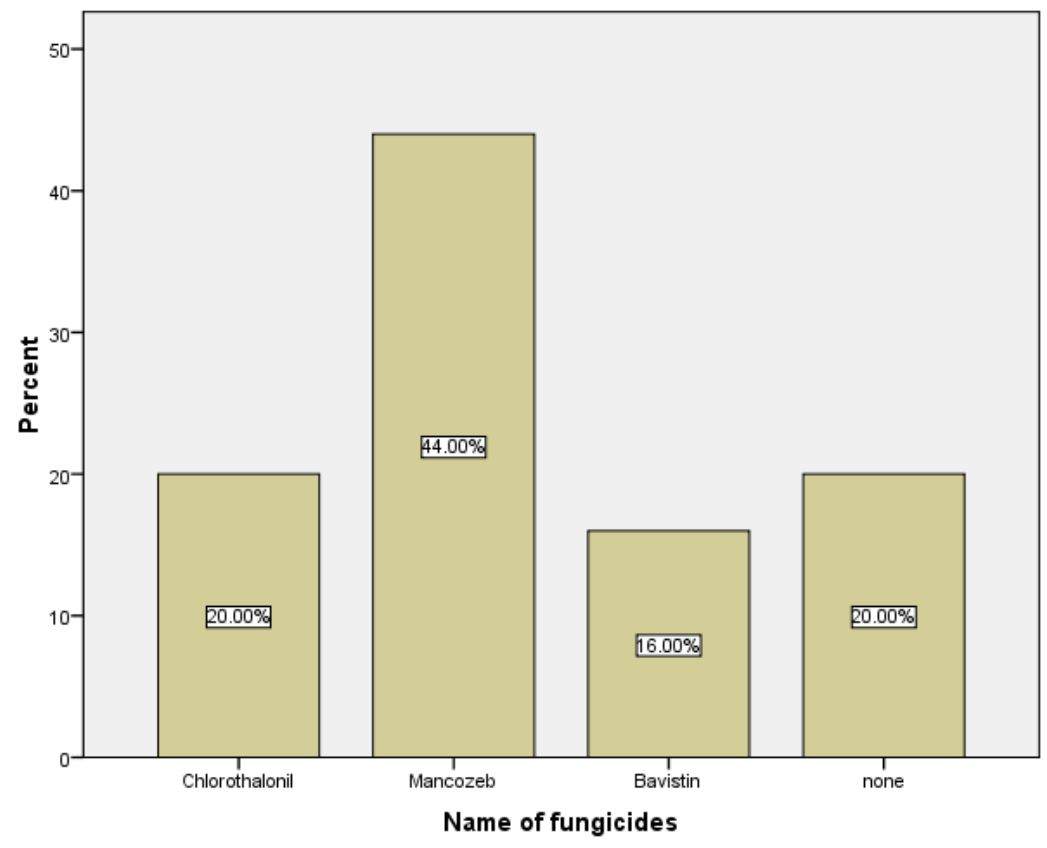

Figure 6. Synthetic fungicides used in tomato farms by respondents to control Septoria leaf spot

\subsection{Crop rotation as measure to management of the disease}

Among twenty five tomato growers sixty percent had practice of crop rotation while rest does not. Farmers used crucifers like cabbage, cauliflower etc. This indicates still there is a favorable environmental condition for Septoria fungus to persist year after year in their farm.

Frequency of crop rotation done by twenty five tomato growers is shown in following piechart:

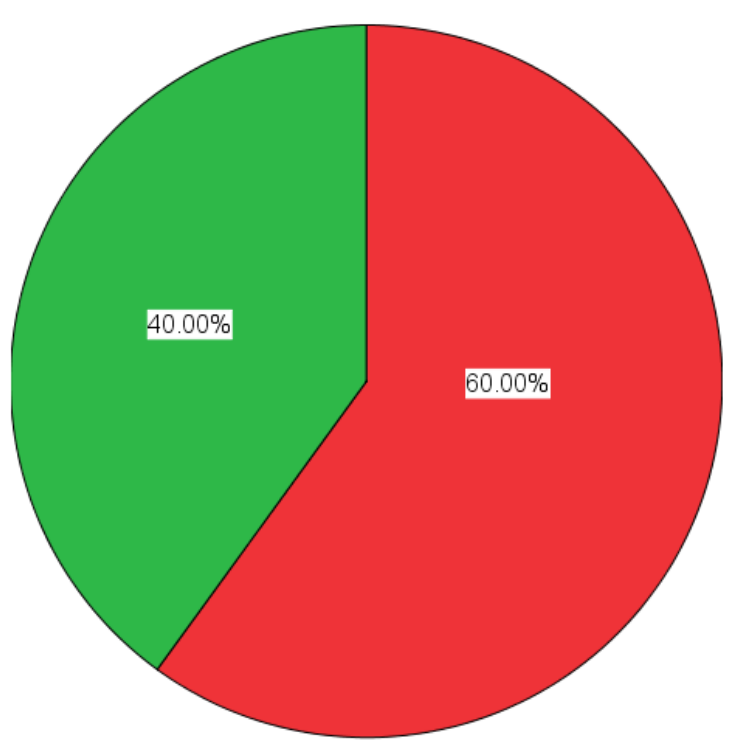

Figure 7. Crop rotation done in farm by respondents 


\subsection{Yield loss}

Seventy two percent of the farmers responds the loss incurred due to the Septoria disease was less than 10\%. Eight percent had 10-20\% yield loss, four percent had $41-60 \%$ yield loss. Sixteen percent had no disease symptoms.

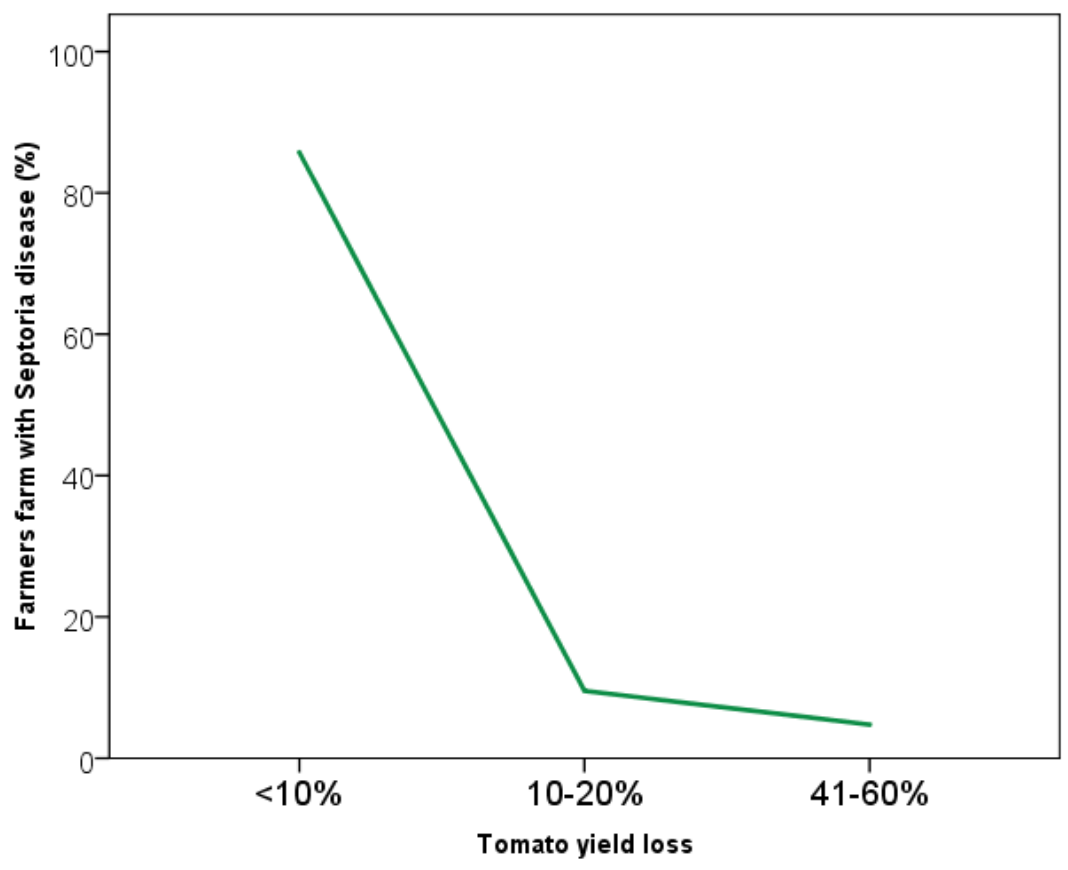

Figure 8. Yield loss due to Septoria leaf spot disease

\subsection{Plastic House Study}

The difference in disease severity in application of the treatments at 45 DAT is nonsignificant. Mancozeb @ 2.5gm/lt was found to be significant in disease control at 55 DAT. It was followed by Chlorothalonil @ 2.5gm/lt water. Disease severity was highest in control.

Disease severity was lowest equally on application of Mancozeb @ 2.5gm/lt and Chlorothalonil @ 2.5gm/ltwater at 65 DAT. Disease severity was highest in control.

On forth application (75DAT) of treatments, Mancozeb found to be the best in controlling the disease, followed by Chlorothalonil. Control was found to be the worst in disease severity, followed by cow urine @ 5\% concentration and mixed application of Neem $(2 \mathrm{ml} / \mathrm{lt})+$ cow urine (5\%) with proportion of 1:1@ $2 \mathrm{ml} / \mathrm{lt}$ water.

In comparing the efficacy in controlling the disease between the synthetic fungicide and bio-products; synthetic fungicides i.e. Mancozeb and Chlorothalonil had better efficacy than bioproducts i.e. cow urine, Neem and combination of cow urine and Neem. Between the two synthetic fungicides Mancozeb had better efficacy in disease control. 
Table 6 Efficacy of treatments to control Septoria leaf spot disease in plastic house during June to October, 2014 at Bhaktapur

\begin{tabular}{|c|c|c|c|c|c|}
\hline \multirow[t]{2}{*}{ Treatments } & \multirow[t]{2}{*}{ Concentration and dose } & \multicolumn{4}{|c|}{ Mean disease severity index $(0-4$, scale $)$} \\
\hline & & 45DAT & $55 \mathrm{DAT}$ & $65 \mathrm{DAT}$ & 75 DAT \\
\hline Killer 15 & $\begin{array}{l}1500 \mathrm{ppm} \text { in liquid form used } \\
\text { @ } 2 \mathrm{ml} / \mathrm{l} \text { water }\end{array}$ & 2.5 & $2.25^{\mathrm{abc}}$ & $2.75^{\mathrm{b}}$ & $3.25^{\mathrm{ab}}$ \\
\hline Cow urine & $5 \%$ conc. of urine & 2.5 & $2.75^{\mathrm{a}}$ & $2.75^{b}$ & $2.75^{\mathrm{b}}$ \\
\hline $\begin{array}{l}\text { Neem } \\
\text { urine }\end{array}$ & $\begin{array}{l}1: 1 \text { ratio; final conc. } 2 \mathrm{ml} / 1 \\
\text { water }\end{array}$ & 2 & $2.50^{\mathrm{ab}}$ & $2.5^{\mathrm{b}}$ & $2.75^{\mathrm{b}}$ \\
\hline Chlorothalonil & $2.5 \mathrm{gm} / 1$ water & 2 & $1.5^{\mathrm{bc}}$ & $1.5^{\mathrm{c}}$ & $1.5^{\mathrm{c}}$ \\
\hline Mancozeb & $2.5 \mathrm{gm} / 1$ water & 1.5 & $1.25^{\mathrm{c}}$ & $1.25^{\mathrm{c}}$ & $0.5^{\mathrm{d}}$ \\
\hline Control & - & 2 & $3^{\mathrm{a}}$ & $3.75^{\mathrm{a}}$ & $4^{\mathrm{a}}$ \\
\hline Mean & & 2.08 & 2.21 & 2.42 & 2.46 \\
\hline LSD & & NS & 1 & 0.78 & 0.87 \\
\hline $\mathrm{CV}(\%)$ & & 25.29 & 30.65 & 21.81 & 23.97 \\
\hline
\end{tabular}

$\mathrm{CV}$ :Coefficient of variation; LSD:Least Significant Difference; SEm: standard error

\subsection{Plant height}

Difference between the treatments in plant height is non-significant. It is also nonsignificant with the number of times of treatment applied.

Table 7. Efficacy of treatments in plant height by controlling Septoria leaf spot disease in plastic house during June to October, 2014 at Bhaktapur

\begin{tabular}{llccc}
\hline Treatments & Concentration and dose & \multicolumn{3}{l}{ Plant height (in cm) } \\
& & 45DAS & 55 DAS & 65 DAS \\
\hline Killer 15 & 1500 ppm in liquid form & & & \\
& used @ 2ml/lt water & $44.563^{\mathrm{a}}$ & $59.688^{\mathrm{a}}$ & $68.938^{\mathrm{a}}$ \\
& 5\% conc. of urine & $46.563^{\mathrm{a}}$ & $67.375^{\mathrm{a}}$ & $78.750^{\mathrm{a}}$ \\
Cow urine & 1:1 ratio; final conc. 2ml/1 & & & \\
Neem + cow-urine & water & $49.188^{\mathrm{a}}$ & $62.125^{\mathrm{a}}$ & $75.646^{\mathrm{a}}$ \\
& 2.5gm/l water & $48.500^{\mathrm{a}}$ & $60.938^{\mathrm{a}}$ & $69.813^{\mathrm{a}}$ \\
Chlorothalonil & 2.5gm/1 water & $50.438^{\mathrm{a}}$ & $67.125^{\mathrm{a}}$ & $78.000^{\mathrm{a}}$ \\
Mancozeb & Water spray & $49.313^{\mathrm{a}}$ & $61.563^{\mathrm{a}}$ & $69.375^{\mathrm{a}}$ \\
Control & & 48.09 & 63.14 & 73.40 \\
Mean & & 11.29 & 17.75 & 20.20 \\
LSD & & 15.81 & 18.93 & 18.52 \\
CV $(\%)$ & & & &
\end{tabular}

$\mathrm{CV}:$ Coefficient of variation; LSD:Least Square Difference

\section{SUMMARY AND CONCLUSION}

Septoria Leaf Spot is one of the important disease of tomato in Bhaktapur with direct yield loss of fourteen percent. But, the disease was not taken seriously. So, detail study on the disease along with disease control measure is done.

Field survey was done representing the whole Bhaktapur district. It was done to study prevalence of Septoria leaf spot in Tomato at field condition. Disease was more prevalent at the 
field of commercial tomato growers. It is the third main disease to the tomato growers. It covers farms of eighty four percent of farmers.

The symptom of the disease is primarily found in leaf and stem. Nearly eighty six percent of farmer's farms have the disease since 1-2 years only. So, the disease is new in Bhaktapur. But it is prevalent throughout the district. Incidence of the disease in tomato plant is observed for around forty two percent.

Environmental conditions of high temperature, relative humidity and precipitation have positive correlation with the disease development.

The disease severity on tomato plants is observed to be fifty two percent.

Synthetic fungicides i.e. Mancozeb and Chlorothalonil were observed as the major disease control measures. These were more effective and fast controlling fungicides than bio-products. Mancozeb was the best one among all the synthetic and bio-products. In bio-products, combination of neem $(2 \mathrm{ml} / \mathrm{l})+$ cowurine $(5 \%)$; $1: 1$ ratio; final solution $2 \mathrm{ml} / \mathrm{l}$ water has better efficacy followed by cow urine; $5 \%$ conc. of urine.

\section{LITERATURE CITED}

Agrios, G. N. Plant Pathology. 2005. $5^{\text {th }}$ Ed. Acad. Press, London. 2005. Pp 202, 286, 410 - 413, 453.

Akhter, N., M. F. Begum, S. Alam, and M. S. Alam. 2006. Inhibitory effect of different plant extracts, cow dung and cow urine on conidial germination of Bipolaris sorokiniana. Journal of Bio-Sciences14:87-92.

Annual Report. 2009/010. Plant Pathology Division (PPD), Nepal Agricultural Research Council (NARC), Khumaltar.

Basak, A. B. and M. W. Lee. 2002. Invitro inhibitory activity of cow urine and cow dung of Fusarium solani f. sp. cucurbitae. Mycobiology 30 (1): 51-54.

Deshmukh, S. S. , Rajgure S. S., Ingole S. P. Antifungal activity of cow urine. IOSR Journal of Pharmacy.Vol. 2 Issue 5, Sep-Oct. 2012, pp. 27-30.

Ferrandino, F. J. and W. H. Elmer. Reduction in tomato yield due to Septoria leaf spot. Plant Disease, St. Paul, v.76, n.2, p.208-211, 1992.

Kashyap, A. 2013. Studies on leaf spot of tomato caused by Septoria lycopersici Speg. Karnataka J. Agric. Sci., 26 (3): (454-487) 2013

Kaushik B, I. Chattopadhyay, R. K. Banerjee and U. Bandyopadhyay. Biological activities and medicinal properties of Neem (Azadirachta indica), Current Sci. 2002; 82(11):1336-1345.

Khan, M. I. and R. Kumar. 1990. Antifungal activity of leaf extracts of neem on seed mycoflora of wheat. Indian J. Appl. Pur. Biol. 5 (1): 13-14.

Lincoln, R. G. and G. B. Cummins. Septoria Blight resistance in tomato. Phytopathology,vol 39. pp 647-655. 1949.

MacNeill, B.H. 1950. Studies in Septoria lycopersici Speg. Can. J. Res. 28:645-672.

Pandey, Y. R., A. B. Pun, and K. P. Upadhyay. 2006. Participatory varietal evaluation of rainy season tomato under plastic house condition. Nepal Agriculture Research Journal 7: 11-15.

Parker, S. K, F. W. Nutter Jr, and Gleason M. L. 2001. Directional spread of septoria leaf spot in Tomato rows. Plant Dis. 81: $272-276$.

Satterthwaite, S. 1988. Mancozeb and ETU Residues in Tomatoes: Re- port No.34A-88-51. Unpublished study prepared by Enviro-Bio- Tech, Ltd. 39 p. 
Siddharth, V. and K. Miglani. Synergistic antimicrobial effect of cow urine and Azadirachta indica on infectious microbes. International Journal of Pharmaceutical Sciences and Research. 2011.

Sohi, M. S. and S. S. Sokhi. Morphological, physiological and pathological studies in Septoria lycopersici. Indian Phytopathology, New Delhi, v.26, n.4, p.666-673, 1974.

Sutton, B. C., Waterston, J. M. Septoria lycopersici. Kew: Commonwealth Mycological Institute, 1996. N.89: Descriptions of pathogenic fungi and bacteria: p.1-2.

US EPA. 1999. Reregistration Eligibility Document (RED)- Chlorothanonil. Office of Pesticide Programs, Washington DC

Watt, B. A. 2000. Septoria leaf spot of Tomato. University of Maine-fact Sheet. http: pmo.umext.maine.edu/factsht/septum.htm. 